\title{
Students' Perception Towards Online Learning at University During COVID-19 in Nepal
}

- Gunja Kumari Sah**

\begin{abstract}
The COVID-19 pandemic has forced the closure of educational institutions worldwide. The study reports the students' perception of online learning during the COVID-19 pandemic. The research was constructed using a descriptive research design. Data were obtained from the 225 students of Tribhuvan University, Kathmandu University, Purbanchal University, Pokhara University, and Rajarshi Janak University through simple random sampling techniques and entered into SPSS version 20 for the analysis. The result revealed that online learning was less effective than physical learning. The majority of respondents, $69 \%$ at each university, state that online learning was less effective than physical learning. In contrast, $19 \%$ believe it was more successful, a nd12 \% believe it was the same. It is probably due to a lack of genuine engagement and feelings of isolation that impeded online learning. However, M.Phil. and Ph.D. students were enthused about online learning. They considered online learning to be precious. It also found that students at Kathmandu University felt online learning was beneficial. Several elements, including teachers, students, management, and government legislation, influence online learning success, particularly pandemics.
\end{abstract}

Keywords: - COVID-19, Online Learning, Students Perception, University

\section{Background of the Study}

COVID-19, a member of the severe acute respiratory syndrome (SARS) coronavirus-2 (SARS-CoV- 2) family, first surfaced in Wuhan, the capital city of Hubei province in the People's Republic of China, in December 2019, and has drastically changed global perceptions of online learning. In the end of 2019, the WHO China Country Office received notification of cases of pneumonia with uncertain etiology in Wuhan, Hubei Province, China. China's national authorities reported 44 case-patients with pneumonia of unclear cause to WHO between December 31, 2019, and January 3, 2020. The causative agent was not discovered throughout this period. The World Health Organization (WHO) proclaimed

\footnotetext{
${ }^{10}$ Mrs.Sah is an Assistant Professor of Management, Patan Multiple Campus, TU,Nepal
} 
the virus an international public health emergency and a pandemic (WHO, 2020) on January 31, 2020. During the COVID-19 pandemic, businesses, universities, and schools worldwidewere shut down. UNESCO has released the data on school/college closures affecting 1.5 billion children and youth in 195 nations, ranging from pre-primary to higher education. Even though this number is decreasing, 1.3 billion students in 186 countries remain unable to attend school (UNESCO, 2020).

Most colleges throughout the world have begun to offer their courses online using various teaching-learning technologies (Acharya et al., 2020; Gautam and Gautam, 2021; Gopal et al., 2021; Imsa-ard, 2020; Khan et al., 2020; Sharmaet al., 2020; Thomas, 2020). Across the globe, the mode of teaching-learning activities is being forced to shift from physical classroom teaching to virtual online teaching. Regardless of other countries, Nepal is affected by COVID-19, which has resulted in the loss of regular college activities for over 441,819 students (UGC, 2019), and universities have been compelled to postpone examination and admission schedules. The COVID-19 has adversely affected the education sector.

In the current COVID 19 pandemic condition, the contribution of information technology has gained pace due to the closure of educational institutions, which poses barriers to students' learning. Information technology serves as a solution for the continuous learning process during quarantine period through creative and learning management systems. It has allowed educators to adopt Information Technology solutions for teaching and evaluating students' completion of course work. Different stakeholders, such as instructors, students, and administrators, were working together to make the most use of technology and ensure an efficient learning experience (Khan et al., 2020).

Institutions and students worldwide have embraced and valued the online learning platform. The ease of use, time flexibility, customizable environment from instructor and management are the reasons for its acceptability. Despite its numerous benefits, online learning has several drawbacks, including social isolation and lack of face-to-face interaction, technological knowledge, skills, internet problem, heavy investment to purchase mobile, tablet, or laptop, and learning autonomy (Imsa-ard, 2020; Khan et al., 2020; Thomas, 2020). According to UNESCO, the pandemic had disrupted learning for 9 out of 10 kids (87 percent) worldwide, preventing thousands of pupils from attendingschool or college (UNESCO, 2020). Online learning was never adopted and acknowledged as actual learning or the formal manner of education before this ongoing pandemic forced the world to resort to electronic learning alternatives.

In Nepal, there are eleven full universities: Tribhuvan University (TU), Nepal Sanskrit University (NSU), Kathmandu University (KU), Purbanchal University (PU), Pokhara 
University (PokU),Lumbini Bauddha University (LBU)), Far-Western University (FWU), Mid-Western University (MWU), Agriculture and Forestry University (AFU), Nepal Open University, and Rajarshi Janak University, as well as four medical academies (NAMS), B.P. Koirala Institute of Health Sciences (BPKIHS), Patan Academy of Health Sciences (PAHS), and Karnali Academy of Health Sciences (KAHS) (UGC, 2019).

There are 1141 TU campuses (61 constituents and 1080 affiliated campuses). PU, PokU, and $\mathrm{KU}$ are the other prominent universities in student numbers. These institutions have over 18000 students and more than 20 campuses: PU has 116 (8.1\%) campuses, PoKU has 67 (4.68\%) campuses, and KU has $24(1.68 \%)$ campuses. Four hundred forty-one thousand eight hundred nineteen $(441,819)$ students enrolled in higher education in the 2018-19 academic years (UGC, 2019).

In terms of provinces, 621 (43.37 \%) campuses are in Bagmati Province, 185 (12.92 \%) in Lumbini Province, 196 (13.69 \%) in Province One, 123 (8.59\%) in Province Two, 151 (10.54 \%) in Gandaki Province, 95 (6.63\%) in Sudurpaschim Province, and 61 (4.26 \%) campuses in Karnali Province. In terms of the number of students, TU has 335,543 (75.95 \%) students, PokU has 30,542 (6.91 \%) students, PU has 27,527 (6.23 \%) students, and KU has $18,356(4.15 \%)$ students and RJU has $153(0.035 \%)$ students enrolled in universities (UGC, 2019).

Tribhuvan University, Nepal's oldest and largest university, serves students from various socioe-conomic backgrounds, particularly the poor, middle, and high classes. All universities in Nepal, except a distance mode university, have used the virtual class teaching mode for almost all of their programs before Covid-19 (UGC, 2019). However, online learning is new to every university except distance mode university. All stakeholders, including instructors, students, administrators, and the government, are still adjusting to this unique teaching and learning approach (Gautam and Gautam, 2021; K.C., 2020; Sharma et al., 2020).

In the current Covid-19 situation of the virtual teaching-learning process, it is critical to explore learners' perceptions and explain their preferences towards this novel teaching methodology. The degree of adaptation and, if any, amendments they would like to suggest for the same, or their desire to reject it entirely and any improvements (Erlianaet al., 2021; Khan et al., 2020; Thomas, 2020; Timperly et al., 2007).

Faculty, administrative personnel, students have difficulties and hurdles in deciding on an online mode of education due to a lack of prior preparation and convincing institutional infrastructure. Therefore, this study rigorously addresses major research questions, which are as follows. 
- What are the present statuses of students' perception of online learning at University during Covid-19?

- Do any differences between students' perception by demography and geography features?

- Are students' perceptions affected by the level of education?

On the basis of research questions, the research objectives are as follows:

- To assess the present status of students' perception of online learning at University during Covid-19.

- To assess students' perception by demography and geography features.

- To evaluate students' perception of the level of education.

Online learning becomes effective and successful when instructors, learners, and management are entirely involved in the online teaching and learning process. Building an online education system is significant to create an education-friendly curriculum, updated technology, motivated faculty, and a proactive management system. Thus, active involvement and teamwork of all stakeholders areessential to minimize the potential adverse effect of the move from physical learning to online learning. As this study was limited to only five major Universities, more research should be done on the entire university and a global estimate.

\section{Literature Review}

Online education is still relatively new, constantly evolving due to fast-changing technologies. All online educators must put more effort into integrating pedagogy with technologyto improve student learning (Khan et al., 2020). Barbour (2006) expressed concern about the digital divide and the impact of different countries' pedagogical techniques on students' online learning experiences. Digital readiness refers to a country's availability and utilization of information technology and infrastructures. The number of studies investigating students' perspectives of online learning has expanded in recent years due to technological improvements. Due to Covid-19, there has been a boom in research into students' perceptions of online learning.

In Nepal, Sharma et al. (2020) found 82.4\% of the students of Chitwan Medical College felt that they needed to be updated with the latest technology. They also discovered that the majority of students were pleased with the timely response from the concerned faculties and departments over the internet and the content of the lessons. One of the essential variables in students' acceptance and success of the learning process was the efficiency and efficacy of e-learning-based components. 
Paudel (2020) conducted a study on the perspectives of 280 teachers and students from five universities in Nepal, including Tribhuvan University, Kathmandu University, Mid-western University, Far-western University, and Pokhara University. The participants found online education beneficial primarily for promoting online research, connecting practitioners to the global community, obtaining an extensive and authentic knowledge resource. However, they identified time management skills, more freedom for teachers and learners, and reliable internet at work as extreme challenges. The study also discovered that time management skills, technological preparedness, and computer literacy are essential attributes for online education practitioners.

Tribhuvan University and Kathmandu University in Nepal, a few organizations, have begun to provide teacher training. In addition, university administrators must ensure that every student has access to technology and the internet (Dawadi et al., 2020). All stakeholders must actively participate and collaborate to reduce the potential adverse effects of the move from traditional learning to e-Learning (K.C., 2020).

In India Khan et al. (2020) identified the value of e-learning in the COVID-19 pandemic. Elearning has evolved to increase the learning process, with social media potentially enhancing the learning output even further. Students believed that online programs were appealing because of their flexibility and convenience. Still, broadband connectivity concerns in remote locations make it difficult for students to participate in online learning efforts (Muthuprasad et al., 2021).

Yan et al. (2021) conducted a province-wide survey in China to learn about Students' experiences with online learning during the COVID-19 pandemic. They discovered that online learning experiences change significantly between school years. Mollah and Parvin (2020) researched online higher education during the Covid-19 Pandemic in Bangladesh. The results demonstrated that online classes were useless for a long time because higher education was highly technical, professional, specialized, based on practical, lab tests, and field survey data. Expensive internet connections and connection loss were two of the most typical problems students and teachers confront. Khan et al.(2021) also found online classes influencing mental health.

According to the logistic model in Thailand, Thomas (2020) discovered that students who were not freshmen or majored in information technology were substantially less likely to be active e-learning users. Ard (2020) found most students preferred face-to-face classrooms over online learning, and the majority were unwilling to learn online in the future.

Alsoud and Harasis (2021) studied Jordanian university students' e-learning experiences and e-learning readiness throughout the epidemic. They discovered that students from remote 
and impoverished locations encountered numerous problems, including limited technical access, poor internet connectivity, and difficult study conditions. Romania established a method to prevent and control the spread of the SARS-COV2 virus. Traditional courses have been temporarily discontinued at schools, high schools, and universities while transitioning to an online education model (Butnaru et al., 2021).

The most critical concerns were technological issues, followed by teachers' lack of technical abilities and instructional styles that were not effectively fitted to the online context (Coman et al., 2020). Computer-assisted education, distance learning, and the internet were not commonly used in agriculture programs due to a lack of resources (Shinn, 1997). Technical challenges with technical gadgets may also impact students' online learning perceptions (Acharya et al., 2020; Khan et al., 2020; Mollah and Parvin, 2020; Paudel, 2020; Yan et al., 2021).

Aristovnik et al. (2020) researched how pupils see the global impacts of the first wave of COVID-19 crisis in early 2020 on many elements of their lives. Despite the international shutdown and move to online learning, the study found that students were most satisfied with the assistance offered by teaching staff and their university contacts, based on a sample of 30,383 students from 62 countries. Students were primarily concerned about their future careers, studies, everyday boredom, anxiety, and frustration. There were also disadvantages that the online teaching environment cannot be recognized due to inefficiency of computer skills and the perception of an immense burden (Gherheș et al., 2021).

Online learning was less appealing to students and less effective in learning and teaching than face-to-face learning. Furthermore, online education has various drawbacks, such as the lack of a suitable internet network and access to online learning. Students felt less driven to learn online (Azhari and Kurniawati, 2021).

\section{Methodology}

The current study was conducted using a quantitative method based on the survey method. A descriptive research approach was adopted to achieve research objectives. The study's populations were students from the oldest Tribhuvan University, Kathmandu University, Purbanchal University, Pokhara University, and newly established Rajarshi Janak University. The research sample contained 220 students from the aforementioned significant universities. According to Sekaran and Bougie (2016), sample greater than 30 but smaller than 500 is adequate for the research. Cooper and Schindler (2014) suggested sample size of at least 385 respondents for the research. The sample size accepted scientific standard for the study (Krejcie and Morgan, 1970). A structured questionnaire called seven-point Likert Scales designating "7 - strongly agree" to " 1 - strongly disagree" is used as the research 
tool, which was prepared in Google Docs. The information was gathered using a simple random sampling techniques via an internet poll between February and March 2021. Internet surveys are less time-consuming, cost less money, and maybe finished in days rather than weeks or months (Paudel, 2020). The descriptive approach was used to analyzed data after entering it into a statistical package for the social sciences.

\section{Data Analysis, Results, and Discussion}

The study includes the experience of students of TU, KU, PU, PokU and the newly established RJU. Table 1 illustrates the results of the questions on gender, age group, marital status, employment status, faculty, and system with levels of study.

Table 1: Demographic Profile of Respondents

\begin{tabular}{|c|c|c|c|c|c|c|}
\hline \multicolumn{2}{|c|}{ Demographic Status } & Bachelor's & Master & M. Phil & Ph D. & Total \\
\hline \multirow[t]{2}{*}{ Gender } & Male & 65 & 45 & 5 & 5 & 53.33 \\
\hline & Female & 53 & 44 & 4 & 4 & 46.67 \\
\hline \multicolumn{2}{|r|}{ Total } & 118 & 89 & 9 & 9 & 100 \\
\hline \multirow[t]{4}{*}{ Age Group } & $15-24$ & 107 & 22 & 0 & 0 & 57.33 \\
\hline & $25-34$ & 8 & 59 & 4 & 0 & 31.56 \\
\hline & $35-44$ & 3 & 8 & 3 & 1 & 6.67 \\
\hline & Above 45 & 0 & 0 & 2 & 8 & 4.44 \\
\hline \multicolumn{2}{|r|}{ Total } & 118 & 89 & 9 & 9 & 100 \\
\hline \multirow[t]{3}{*}{ Marital Status } & Unmarried & 111 & 59 & 4 & 0 & 77.33 \\
\hline & Married with no child & 7 & 20 & 0 & 0 & 12.00 \\
\hline & Married with children & 0 & 10 & 5 & 9 & 10.67 \\
\hline \multicolumn{2}{|r|}{ Total } & 118 & 89 & 9 & 9 & 100 \\
\hline \multirow{4}{*}{$\begin{array}{l}\text { Employment } \\
\text { status }\end{array}$} & Private Employed & 20 & 28 & 5 & 0 & 23.56 \\
\hline & Government Employed & 2 & 3 & 3 & 9 & 7.56 \\
\hline & Unemployed & 87 & 50 & 0 & 0 & 60.89 \\
\hline & Other & 9 & 8 & 1 & 0 & 8 \\
\hline \multicolumn{2}{|r|}{ Total } & 118 & 89 & 9 & 9 & 100 \\
\hline \multirow[t]{4}{*}{ Faculty } & Science & 21 & 48 & 0 & 5 & 32.89 \\
\hline & Management & 88 & 39 & 5 & 1 & 59.11 \\
\hline & Humanities & 3 & 2 & 4 & 3 & 5.33 \\
\hline & Education & 6 & 0 & 0 & 0 & 2.67 \\
\hline \multicolumn{2}{|r|}{ Total } & 118 & 89 & 9 & 9 & 100 \\
\hline System & Annual & 30 & 3 & 1 & 2 & 16.00 \\
\hline
\end{tabular}




\begin{tabular}{|c|c|c|c|c|c|}
\hline Semester & 88 & 82 & 8 & 7 & 82.22 \\
\hline Trimester & 0 & 4 & 0 & 0 & 1.78 \\
\hline Total & $\mathbf{1 1 8}$ & $\mathbf{8 9}$ & $\mathbf{9}$ & $\mathbf{9}$ & $\mathbf{1 0 0}$ \\
\hline
\end{tabular}

Source: Online Survey, 2021

Table 1 shows a profile of the survey participants' personal information. The majorities of students were males 65 with $53.33 \%$, between the ages of 15 to 24 with 107 with $(57.33 \%)$, unmarried 111 with $77.33 \%$, unemployed 87 with $60.89 \%$, and enrolled in a management program 88 with $59.11 \%$ in a semester schedule. In terms of study levels, most students of bachelor's degree 118 with $52.44 \%$ followed by master's 89 with 39.56\%, Mphil, and Ph.D. degrees 9 with 4\%. The geographical features of responders from various universities are shown in Table 2.

Table 2: Geographic Profile of Respondents

\begin{tabular}{|c|c|c|c|c|c|c|}
\hline \multirow[t]{2}{*}{ Province } & \multicolumn{5}{|l|}{ University } & \multirow[t]{2}{*}{ Total } \\
\hline & $\begin{array}{l}\text { Tribhuvan } \\
\text { University }\end{array}$ & $\begin{array}{l}\text { Kathmandu } \\
\text { University }\end{array}$ & $\begin{array}{l}\text { Purbanchal } \\
\text { University }\end{array}$ & $\begin{array}{l}\text { Pokhara } \\
\text { University }\end{array}$ & $\begin{array}{l}\text { Rajarshi } \\
\text { Janak } \\
\text { University }\end{array}$ & \\
\hline \multirow[t]{2}{*}{1} & 14 & 3 & 5 & 2 & 0 & 24 \\
\hline & $58.30 \%$ & $12.50 \%$ & $20.80 \%$ & $8.30 \%$ & $0.00 \%$ & $100.00 \%$ \\
\hline \multirow[t]{2}{*}{2} & 17 & 7 & 27 & 3 & 16 & 70 \\
\hline & $24.30 \%$ & $10.00 \%$ & $38.60 \%$ & $4.30 \%$ & $22.90 \%$ & $100.00 \%$ \\
\hline \multirow[t]{2}{*}{ Bagmati } & 76 & 9 & 1 & 5 & 0 & 91 \\
\hline & $83.50 \%$ & $9.90 \%$ & $1.10 \%$ & $5.50 \%$ & $0.00 \%$ & $100.00 \%$ \\
\hline \multirow[t]{2}{*}{ Gandaki } & 5 & 1 & 0 & 5 & 0 & 11 \\
\hline & $45.50 \%$ & $9.10 \%$ & $0.00 \%$ & $45.50 \%$ & $0.00 \%$ & $100.00 \%$ \\
\hline \multirow[t]{2}{*}{ Lumbini } & 15 & 2 & 0 & 0 & 0 & 17 \\
\hline & $88.20 \%$ & $11.80 \%$ & $0.00 \%$ & $0.00 \%$ & $0.00 \%$ & $100.00 \%$ \\
\hline \multirow[t]{2}{*}{ Karnali } & 4 & 1 & 0 & 0 & 0 & 5 \\
\hline & $80.00 \%$ & $20.00 \%$ & $0.00 \%$ & $0.00 \%$ & $0.00 \%$ & $100.00 \%$ \\
\hline \multirow{2}{*}{$\begin{array}{l}\text { Sudurpas } \\
\text { hchim }\end{array}$} & 6 & 1 & 0 & 0 & 0 & 7 \\
\hline & $85.70 \%$ & $14.30 \%$ & $0.00 \%$ & $0.00 \%$ & $0.00 \%$ & $100.00 \%$ \\
\hline \multirow[t]{2}{*}{ Total } & 137 & 24 & 33 & 15 & 16 & 225 \\
\hline & $60.90 \%$ & $10.70 \%$ & $14.70 \%$ & $6.70 \%$ & $7.10 \%$ & $100.00 \%$ \\
\hline
\end{tabular}

Source: Online Survey, 2021

Table 2 indicates that most students 137 with $60.90 \%$ from each province studying at TU except Province 2. The majority of Province 2 students, 27 with $38.6 \%$, are studying at PU, followed by TU with $24.3 \%$, RJU with $22.90 \%$, KU with $12.50 \%$, and PokU with $8.30 \%$. All universities in Nepal used the virtual class teaching style for practically all of their programs during Covid-19 (Gautam, 2021). All stakeholders, including instructors, students, 
administration, and the government, are still adjusting to this new teaching, learning approach. Students' perceptions towards online learning are depicted in Figure 1.

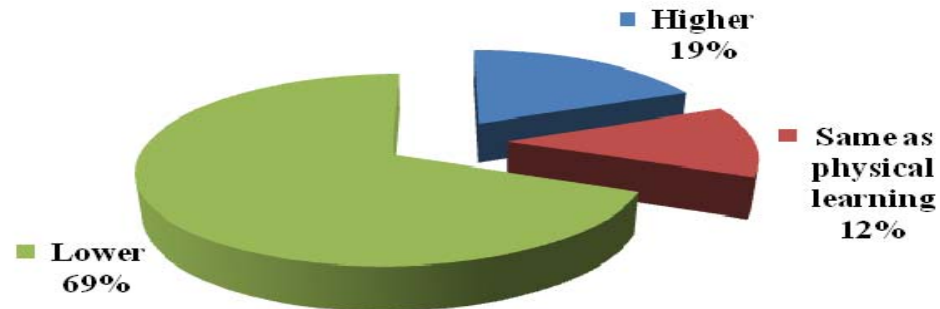

Figure

1:Overall

Students'

Perception towards Online Learning

Figure 1 shows that $69 \%$ of students believe online learning is less effective than physical learning, $19 \%$ believe it is more effective, and $12 \%$ believe it is the same. Paudel (2020) reported a significant disparity between online and physical classes in the context of Nepal.

Table 3: Perception toward Online Learning by Province

\begin{tabular}{|c|c|c|c|c|}
\hline \multirow{2}{*}{ Province } & \multicolumn{3}{|c|}{ Perception Toward Online Learning } & \multirow{2}{*}{ Total } \\
\cline { 2 - 5 } & Higher & Same as physical learning & Lower & 23 \\
\hline 1 & 1 & 3 & 19 & $100.00 \%$ \\
\hline 2 & $4.30 \%$ & $13.00 \%$ & $42.60 \%$ & $100.00 \%$ \\
\hline Bagmati & 15 & 11 & $64.90 \%$ & 91 \\
\hline & $20.30 \%$ & $14.90 \%$ & 61 & $100.00 \%$ \\
\hline Gandaki & 18 & 12 & $67.00 \%$ & 6 \\
\hline & $19.80 \%$ & $13.20 \%$ & 3 & $100.00 \%$ \\
\hline Lumbini & 3 & 0 & $50.00 \%$ & 17 \\
\hline & $17.60 \%$ & $0.00 \%$ & $76.50 \%$ & $100.00 \%$ \\
\hline Karnali & 1 & 1 & 4 & 5 \\
\hline & $20.00 \%$ & $5.90 \%$ & $80.00 \%$ & $100.00 \%$ \\
\hline Sudurpashchim & 1 & 0 & 7 & 9 \\
\hline & $11.10 \%$ & $0.00 \%$ & $77.80 \%$ & $100.00 \%$ \\
\hline
\end{tabular}

\section{Pearson Chi-square value 9.99, $\mathrm{P}=\mathbf{0 . 6 1 7}$}

Source: Online Survey, 2021

Table 3 demonstrates that most respondents, 155 with $68.9 \%$, believe online learning is less effective than physical learning, the fewest 42 with $18.7 \%$, believe it is more effective. Very few 28 with $12.40 \%$ believe it is the same as physical learning. Since P-value 0.617 
was more significant than the significance level, i.e., $0.05(5 \%)$, there was no significant relationship between the province and perceptions of online learning. Limited technological infrastructure, socio-economic factors, a lack of experience conducting assessment, supervision in an online mode, increased workload for teachers, education staff, and incompatibility with specific subject matters or cultures have all been identified as challenges by instructors, students, administration, and the government (Alsoud and Harasis, 2021; Gautam and Gautam, 2021; Khan et al., 2021; Thomas, 2020). In this regard, institutions could establish training sessions for teachers, students and programs to encourage favorable perception towards online learning and, implicitly, the quality of the educational process (Coman et al., 2020).

Table 4: Perception towards Online Learning by University

\begin{tabular}{|c|c|c|c|c|}
\hline \multirow{2}{*}{ University } & \multicolumn{3}{|c|}{ Perception Toward Online Learning } & Total \\
& Higher & Same as physical learning & Lower & \\
\hline Tribhuvan & 26 & 16 & 95 & 137 \\
\hline & $19.00 \%$ & $11.70 \%$ & $69.30 \%$ & $100.00 \%$ \\
\hline Kathmandu & 8 & 1 & 15 & 24 \\
\hline & $33.30 \%$ & $4.20 \%$ & $62.50 \%$ & $100.00 \%$ \\
\hline Pokhara & 2 & 0 & 13 & 15 \\
\hline & $13.30 \%$ & $0.00 \%$ & $86.70 \%$ & $100.00 \%$ \\
\hline Purbanchal & 4 & 7 & 22 & 33 \\
\hline & $12.10 \%$ & $21.20 \%$ & $66.70 \%$ & $100.00 \%$ \\
\hline Rajarshi Janak & 2 & 4 & 10 & 16 \\
\hline & $12.50 \%$ & $25.00 \%$ & $62.50 \%$ & $100.00 \%$ \\
\hline Total & $\mathbf{4 2}$ & $\mathbf{2 8}$ & $\mathbf{1 5 5}$ & $\mathbf{2 2 5}$ \\
\hline & $\mathbf{1 8 . 7 0} \%$ & $\mathbf{1 2 . 4 0 \%}$ & $\mathbf{6 8 . 9 0 \%}$ & $\mathbf{1 0 0 . 0 0 \%}$ \\
\hline
\end{tabular}

Pearson Chi-square value 12.36, $P=0.136$

Source. Online Survey, 2021

Table 4 shows that most respondents, 155 with $68.90 \%$ at each university, believe online learning is less successful than physical learning, the fewest 42 with $18.70 \%$, believe it is more effective. However, very few 28 with $12.40 \%$, believe it is the same. Regarding student perceptions of online learning at KU, 8 students (33.30\%) believe that it is beneficial due to its infrastructure, educational strategy, and system assist in becoming acquainted with the online learning system. Therefore, it is critical that every university pay attention to educational methods and learners' concerns while utilizing the online learning system (K.C., 2020). Since P-value 0.136 was more significant than the level of significance, i.e., 0.05 $(5 \%)$, there was nomeaningful relationship between the several university and perceptions towards online learning. 
Table 5: Perception toward Online Learning by Levels of Study

\begin{tabular}{|c|c|c|c|c|}
\hline \multirow{2}{*}{ Levels of Study } & \multicolumn{3}{|c|}{ Perception Toward Online Learning } & \multirow{2}{*}{ Total } \\
\cline { 2 - 5 } & Higher & Same as physical learning & Lower & \\
\hline Bachelor's & 24 & 12 & 82 & 118 \\
\hline & $20.30 \%$ & $10.20 \%$ & $69.50 \%$ & $100.00 \%$ \\
\hline Master's & 9 & 13 & 67 & 89 \\
\hline & $10.10 \%$ & $14.60 \%$ & $75.30 \%$ & $100.00 \%$ \\
\hline M. Phil & 4 & 3 & 2 & 9 \\
\hline & $44.40 \%$ & $33.30 \%$ & $22.20 \%$ & $100.00 \%$ \\
\hline Ph D. & 5 & 0 & 4 & 9 \\
\hline & $55.60 \%$ & $0.00 \%$ & $44.40 \%$ & $100.00 \%$ \\
\hline Total & 42 & 28 & 155 & 225 \\
\hline & $18.70 \%$ & $12.40 \%$ & $68.90 \%$ & $100.00 \%$ \\
\hline
\end{tabular}

Pearson Chi-square value 22.691, $\mathrm{P}=\mathbf{0 . 0 0 1}$

(Source. Online Survey, 2021)

Students in bachelor's and master's degree programs believe that online learning is less effective than traditional learning, as seen in Table 5. While M.Phil. and Ph.D. students are eager about online learning. They consider online knowledge to be beneficial. Therefore, learners' level of study, traits, and technological abilities significantly impact students' approach to online learning. Students who are up to date on the latest technology can complete their studies with ease and satisfaction. However, it was also considered that such seminars could not be a long-term alternative for classroom instruction because higher education is primarily based on practical, lab exams, field visits, professional and highly specialized instruction (Mollah and Parvin, 2020). Since P-value 0.001 was less than the significance level, i.e., $0.05(5 \%)$, there was a significant association between the various levels of study and perceptions towards online learning.

\section{Conclusion}

The lockdown of COVID-19 has caused significant disruptions to academic activities. This research explored students' learning experiences from several Nepalese universities during the COVID-19 pandemic. The results show that online learning is less effective than physical learning.

Most respondents believe online education is less effective than physical learning at each university. The fewest believe it is more effective, and the very least consider it is the same even though students at KU experience differently than others. According to bachelor's and master's degree programs, online learning is less effective than traditional learning. However, M.Phil. and Ph.D. scholars are encouraged about online learning. They believe that online learning is quite advantageous. It revealed a significant relationship between levels of study and online learning perception.

The effectiveness of online learning, particularly in pandemics, is determined by several factors, including instructors, students, administration, and the policy of governments. Therefore, it is regarded as successful teaching when various stakeholders create clear goals. 


\section{Acknowledgments}

The author would like to express gratitude Patan Multiple Campus, Patan Dhoka, Lalitpur, Tribhuvan University for continuous support.

\section{References}

Acharya, A., Poudyal, N., Lamichhane, G., Aryal, B., Bhattarai, B. R., Adhikari, B., Bhatta, M., Gyawali, N., \& Parajuli, N. (2020). Internet-based online higher education in Nepal amidst COVID-19. EdArXiv. https://doi.org/10.35542/osf.io/r85bc

Alsoud, A. R., \& Harasis, A. A. (2021). The impact of Covid-19 pandemic on student's e-learning experience in Jordan. Journal of Theoretical and Applied Electronic Commerce Research, 16(5): 1404-1414. https://doi.org/10.3390/jtaer16050079

Ard, P. I. (2020). Thai University student's perceptions towards the abrupt transition to forced online learning in the COVID-19 situation. Journal of Education Khon Kaen University, 43(3): 30-44.

Aristovnik, A., Keržič, D., Ravšelj, D., Tomaževič, N., \& Umek, L. (2020). Impacts of the COVID19 pandemic on life of higher education students: a global perspective. Sustainability, 12(20): 134. https://doi.org/10.3390/su12208438

Azhari, T., \& Kurniawati. (2021). Student'sperception on online learning during the Covid-19 pandemic: A case study of Universitas Malikussaleh students. Proceedings of the International Conference on Social Science, Political Science, and Humanities (ICoSPOLHUM 2020), 495:46-50. https://doi.org/10.2991/assehr.k.210125.009

Barbour, M. K. (2006). Virtual schools: planning for success, by Zane L. Berge and Tom Clark, eds. (Book Review). The Quarterly Review of Distance Education, 7(2:) 215-218.

Butnaru, G. I., Niță, V., Anichiti, A., \& Brînză, G. (2021). The effectiveness of online education during Covid 19 pandemic-A comparative analysis between the perceptions of academic students and high school students from Romania. Sustainability, 13(9): 1-20. https://doi.org/10.3390/su13095311

Coman, C., Țîru, L. G., Meseșan-Schmitz, L., Stanciu, C., \& Bularca, M. C. (2020). Online teaching and learning in higher education during the coronavirus pandemic: students' perspective. Sustainability, 12(24):1-24. https://doi.org/10.3390/su122410367

Cooper, D. R., \& Schindler, P. S. (2014). Business research methods (Twelth edition). McGrawHill/Irwin.

Dawadi, S., Giri, R., \& Simkhada, P. (2020). Impact of COVID-19 on the education sector in Nepal - challenges and coping strategies. Sage Submission 1-16. https://doi.org/10.31124/advance.12344336.v1

Erliana, H., Nuthihar, R., Jaya, I., \& Herman, R. (2021). Vocational students' perception of online learning during the Covid-19 pandemic. Jurnal Pendidikan Teknologi Dan Kejuruan, 27(1): 57 65.

Gautam, D. K., \& Gautam, P. K. (2021). Transition to online higher education during COVID-19 pandemic: turmoil and way forward to developing country of South Asia-Nepal. Journal of Research in Innovative Teaching \& Learning,14(1):93-111. https://doi.org/10.1108/JRIT-102020-0051

Gherheș, V., Stoian, C. E., Fărcașiu, M. A., \& Stanici, M. (2021). E-learning vs. face-to-face learning: analyzing students' preferences and behaviors. Sustainability,13(8): 1-15. https://doi.org/10.3390/su13084381 
Gopal, R., Singh, V., \& Aggarwal, A. (2021). Impact of online classes on the satisfaction and performance of students during the pandemic period of COVID 19. Education and Information Technologies. https://doi.org/10.1007/s10639-021-10523-1

K.C., T. (2020). Impact of COVID-19 on University education, Nepal. Tribhuvan University Journal, 35(2): 34-46. https://doi.org/10.3126/tuj.v35i2.36187

Khan, M. A., Kamal, T., Illiyan, A., \& Asif, M. (2021). School students' perception and challenges towards online classes during COVID-19 Pandemic in India: An Econometric Analysis. Sustainability, 13(9): 1-15. https://doi.org/10.3390/su13094786

Khan, M. A., Vivek, V., Nabi, M. K., Khojah, M., \& Tahir, M. (2020). Students' perception towards E-Learning during COVID-19 pandemic in India: An empirical study. Sustainability, 13(1): 114. https://doi.org/10.3390/su13010057

Khan, M. M., Rahman, S. M. T., \& Islam, S. T. A. (2021). Online education system in Bangladesh during COVID-19 pandemic. Creative Education, 12(2): 441-452. https://doi.org/10.4236/ce.2021.122031

Krejcie, R. V., \& Morgan, D. W. (1970). Determining sample size for research activities. Educational and Psychological Measurement, 30(3): 607-610. https://doi.org/10.1177/001316447003000308

Mollah, A. H., \& Parvin, S. (2020). Online higher education during Covid-19 pandemic in Bangladesh: Benefits, Problems and Prospects. Journal of International Politics, 2(4): 23-28.

Muthuprasad, T., Aiswarya, S., Aditya, K. S., \& Jha, G. K. (2021). Students' perception and preference for online education in India during COVID -19 pandemic. Social Sciences \& Humanities Open, 3(1): 1-11. https://doi.org/10.1016/j.ssaho.2020.100101

Paudel, P. (2020). Online education: benefits, challenges and strategies during and after COVID-19 in higher education. International Journal on Studies in Education, 3(2): 70-85. https://doi.org/10.46328/ijonse.32

Sekaran, U., \& Bougie, R. (2016). Research Methods for Business. John Wiley \& Sons, 2016, 447.

Sharma, K., Deo, G., Timalsina, S., Joshi, A., Shrestha, N., \& Neupane, H. C. (2020). Online learning in the face of covid-19 pandemic: assessment of students' satisfaction at Chitwan Medical College of Nepal. Kathmandu University Medical Journal, 18(2): 40-47. https://doi.org/10.3126/kumj.v18i2.32943

Shinn, Y. H. (1997). Teaching strategies, their use and effectiveness as perceived by teachers of agriculture: A national study [Doctor of Philosophy, Iowa State University, Digital Repository]. https://doi.org/10.31274/rtd-180813-8037

Thomas, D. (2020). Thailand University students' e-learning behavior during the Global pandemic. Human Behavior, Development and Society, 21(4): 56-65.

Timperly H, Wilson A, Barrar H, Fung I, University of Auckland, New Zealand, \& Ministry of Education. (2007). Teacher professional learning and development: best evidence synthesis iteration (BES).

UGC (2019), Education management information system: report for higher education 2018/19, University Grants Commission (UGC), Bhaktapur, Nepal.

UNESCO (2020), "Global monitoring of school closures caused by COVID-19" available at: https://en.unesco.org/covid19/educationresponse.

Yan, L., Whitelock-Wainwright, A., Guan, Q., Wen, G., Gašević, D., \& Chen, G. (2021). Students' experience of online learning during the COVID-19 pandemic: A province-wide survey study. British Journal of Educational Technology,52(5): 1-20. https://doi.org/10.1111/bjet.13102 